\title{
Evaluation of Perinatal and Postnatal Outcomes of Delivery Type, Delivery Period and Follow-up Labor in HIV Positive Pregnancies from the Perspective of Fetal Infection
}

\author{
HIV Pozitif Gebeliklerde Seçilen Doğum Şeklinin, Doğum Süresinin ve \\ Doğum Travayı Takibinin Fetal Bulaş Açısından Perinatal ve \\ Postnatal Sonuçlarının Değerlendirilmesi
}

İpek Uzaldı1 (ID ), Aslıhan Şahin²(iD), Eda Karadağ Öncel'(iD), Halil Gürsoy Pala'(iD), Mehmet Yekta Öncel(iD), Dilek Yılmaz Çiftdoğan(iD), Sabri Atalay5(ID), Nisel Yılmaz (ID)

${ }^{1}$ Clinic of Gynecology and Obstetrics, Health Sciences University Tepecik Training and Research Hospital, Izmir, Turkey

${ }^{2}$ Clinic of Pediatrics Infectious Diseases, Health Sciences University Tepeceik Training and Research Hospital, İmir, Turkey

${ }^{3}$ Department of Pediatric, Division of Neonatology, İzmir Katip Çelebi University, İmir, Turkey

${ }^{4}$ Department of Pediatric, Division of Pediatric Infectious Diseases, İmir Katip Çelebi University, İmir, Turkey

${ }^{5}$ Clinic of Clinical Microbiology and Infectious Diseaes, Health Sciences University Tepecik Training and Research Hospital, Izmir, Turkey

${ }^{6}$ Medical Microbiology Laboratory, Health Sciences University Tepecik Training and Research Hospital, İmir, Turkey

Cite this article as: Uzaldı I, Şahin A, Karadağ Öncel E, Pala HG, Öncel MY, Yılmaz Çiftdoğan D, et al. Evaluation of perinatal and postnatal outcomes of delivery type, delivery period and follow-up labor in HIV positive pregnancies from the perspective of fetal infection. J Pediatr Inf 2021;15(1):e19-e25.

* Bu çalışma 2. Uluslararası Dr. Behçet Uz Kongresinde (4-7 Mart 2020) sözel bildiri olarak sunulmuştur.

Abstract

Objective: Human immunodeficiency virus (HIV) was first described in 1981 in the world, and the first case in our country was seen in 1985. The total number of cases is 21.988 as of 30 June 2019, which was 3 in 1985. Considering the transmission routes of HIV positive cases in our country, the rate of transmission from mother to baby seems to be $1 \%$, but it is likely that this ratio will be higher if $48.6 \%$ of all cases are not known.

Material and Methods: In this study, perinatal histories and laboratory features of babies born from HIV-positive mothers are planned to be analyzed retrospectively. As far as possible information on HIV infection and the course of pregnancy has been obtained from the medical records and the perinatal history and laboratory features of HIV-infected mother's babies who delivered between 2009 and 2019 at our hospital were analyzed retrospectively.
Öz

Giriş: İnsan immün yetmezlik virüsü (HIV); dünyada ilk olarak 1981 yılında tanımlanmış olup, ülkemizde ise ilk vaka 1985 yılında görülmüştür. 1985 yıIında toplam üç olan vaka sayısı, 30 Haziran 2019 itibariyle toplam 21.988'dir. HIV bulaş yolları ele alındığında, halen tüm HIV vakalarının \%48.6'sının bulaş yolu bilinememektedir. Bu durum \%1'lik gibi oldukça düşük oranlarda bildirilen anneden bebeğe bulaşın gerçekte daha da yüksek oranlarda olabileceğini düşündürmektedir.

Gereç ve Yöntemler: Bu çalışmada hastanemizde doğum yapan HIV pozitif anneden doğan bebeklerin perinatal öykülerinin ve laboratuvar özelliklerinin incelenmesi amaçlanmıştır. Hastanemizde 2009-2019 yılları arasında doğum yapan HIV ile enfekte anne bebeklerinin perinatal öyküleri ve laboratuvar özellikleri geriye dönük olarak incelenmiş, HIV enfeksiyonuna ve gebelik seyrine ait bilgiler, bulunabildiği kadarıyla tıbbi kayıtlardan elde edilmiştir.

Correspondence Address/Yazışma Adresi

Aslıhan Şahin

Sağlık Bilimleri Üniversitesi

Tepecik Eğitim ve Araştırma Hastanesi,

Çocuk Enfeksiyon Hastalıkları Kliniği,

İzmir-Türkiye

E-mail: aslhansahn@gmail.com

Received: 17.04 .2020 
Results: Fifteen infants' ( $60 \%$ male, $40 \%$ female) mothers were diagnosed in $2(13.3 \%)$ before pregnancy, 7 (46.7\%) of the mothers during pregnancy, and $6(40 \%)$ of the mothers during delivery. It was ascertained that eight mothers (53.3\%) received antiretroviral treatment during pregnancy and 2 (13.3\%) mothers delivered by normal spontaneous vaginal route. Zidovudine prophylaxis was started in one of the babies born with a normal spontaneous vaginal route, and the HIV virus load was still negative after eight weeks of prophylaxis and the prophylaxis was discontinued, the other baby was taken by the mother without permission. Premature membrane rupture was detected in three (20\%) pregnant women, and the longest labor time was 16 hours. Eleven (73.3\%) pregnant women received intravenous zidovudine therapy and 13 (86.6\%) babies received antiretroviral prophylaxis. The viral load of the others was negative except one of the 11 babies whose HIV viral load was examined. The patient with a positive HIV viral load ( 300.000 copies $/ \mathrm{mL}$ ) was born by cesarean at 38 weeks of gestation and her mother was diagnosed during delivery and triple antiretroviral prophylaxis (zidovudine, lamivudine, nevirapine) was started on to baby.

Conclusion: Although HIV prevalence is not high in Turkey, the number of cases has been increasing over the years. Perinatal transmission of the HIV virus from mother to baby can be reduced by measures to be taken before, during and after birth. In particular, it should be ensured that HIV infection is not diagnosed late or missed during pregnancy, and HIV-infected pregnant women should be followed up by centers which specialized in HIV.

Keywords: Human immunodeficiency virus, perinatal transmission, HIV-contacted baby

\section{Introduction}

Although human immunodeficiency virus (HIV) infection emerged in the 1970s for the first time in Central Africa, its clinical picture could be identified in the 1980s. Perinatal transmission from the infected pregnant woman to the baby was recognized in 1982 (1). As of the end of 2018, there are over 37.9 million individuals in the world infected with HIV (2). The number of children aged under 15 years infected with HIV is 1.7 million (4.4\%). Along with reducing perinatal HIV transmission with increasing treatment options for HIV transmission from the mother to the baby, HIV prevalence is increasing in adolescents older than 15 years and young adults (2).

In our country, there are 20.202 HIV (+) individuals reported by detecting HIV confirmation test positive, and there are also 1786 cases of acquired immunodeficiency syndrome (AIDS) from 1985 until June $30^{\text {th }}, 2019$ (3). Considering the number of individuals infected by HIV on yearly basis, there is a progressive increase in the number of individuals infected with HIV (3). Women in the reproductive age group comprise $14.8 \%$ and children under the age of 19 comprise $3.3 \%$ of the individuals infected with HIV. Twenty-five point eight percent of the children aged under 19 years infected with HIV have been infected due to perinatal transmission from mother to baby (3). In line with these data, it can be said that HIV infection is a serious health problem in our country and should not be assessed as a rarely seen condition.

HIV remains a global health problem with an estimated 32 million deaths until today (4). HIV has turned into a chronic disease with the increase in rates of prevention, diagnosis and care, and many HIV positive women wish for pregnancies (5).
Bulgular: HIV ile enfekte anneden doğan 15 bebeğin (\%60 erkek, \%40kız) annelerinin 2'sine (\%13.3) gebelikten önce, 7'sine (\%46.7) gebelik sırasında, 6'sına (\%40) ise doğum sırasında HIV tanısı konulduğu belirlendi. 8 annenin (\%53.3) gebelik sırasında antiretroviral tedavi aldığı, 2 (\%13.3) gebenin normal spontan doğum ile doğum yaptığı saptandı. Normal spontan doğum ile doğan bebeklerden birine zidovudin profilaksisi başlanmış ve izleminde bebeğin sekiz haftalık profilaksi sonrasında HIV viral yükünün halen negatif olduğu görülerek profilaksisi kesilmiş, diğer bebek ise anne tarafından izinsiz olarak götürülmüştür. Göç İdaresi ile iletişime geçilmiş ancak anne ve bebeğe ulaşılamamıştır. 3 (\%20) gebede erken membran rüptürü öyküsü saptanırken, en uzun travay süresi de 16 saat olarak belirlendi. 11 (\%73.3) gebe doğum sırasında intravenöz zidovudin tedavisi ve 13 (\%86.6) bebek antiretroviral profilaksi almıştı. HIV viral yükü bakılmış olan 11 bebeğin biri hariç diğerlerinin viral yükü negatif saptanmıştır. HIV viral yükü pozitif (300.000 kopya/mL) olan olgu 38. gestasyon haftasında sezaryen ile doğmuş olup, annesi doğum sırasında tanı almış, doğum sonrası hastaya üçlü (zidovudin, lamivudin, nevirapin) antiretroviral profilaksi başlanmıştı.

Sonuç: Türkiye'de HIV enfeksiyonu çok sık görülmemekle birlikte, olgu sayısı yıllar içinde giderek artmaktadır. HIV'in anneden bebeğe perinatal geçişi, doğum öncesi, sırası ve sonrasında alınacak önlemler ile azaltılabilir. Özellikle, gebelikte HIV enfeksiyonu tanısının geç konulmaması ya da atlanmaması sağlanmalı ve HIV ile enfekte gebelerin takibi HIV konusunda uzman merkezlerce yapılmalıdır.

Anahtar Kelimeler: İnsan immün yetmezlik virüsü, perinatal geçiş, HIV ile temaslı bebek

In the UK, approximately 1300 HIV positive women give birth annually (6). Perinatal HIV infection from HIV positive mother can occur in the intrauterine period, during labor and delivery, and through breast milk postnatally. Intrauterine transmission risk to the baby is low compared to the possibility of intranatal transmission and is around 5\% (7). Prevention strategies of HIV transmission from the mother to the baby does not only aim at preventing vertical transmission but also protects the mother and the baby in terms of delivery-related complications. In this study, it was aimed to investigate the perinatal and postnatal outcomes of delivery type, delivery period, and labor follow-up in terms of fetal infection in HIV positive women who gave birth between 2009-2019 in our hospital.

\section{Materials and Methods}

Perinatal histories and laboratory features of the babies born from HIV-positive mothers in our hospital between 20092019 were retrospectively reviewed. The mothers of the cases consisted of patients followed by the Obstetrics/Gynecology and Clinical Microbiology and Infectious Diseases Departments of our hospital or those that applied as outpatients or were referred to our hospital for delivery. Information on human immunodeficiency virus infection and the course of pregnancy were obtained from medical records.

This study was conducted with the approval of our hospital's Non-invasive Clinical Research Ethics Board (No: 2019/ 159). Anti-HIV tests were studied with the Chemiluminescence Microparticle Immunoassay method (Architect I1000/I2000, Abbott, USA) in the Medical Microbiology Laboratory. Confirmation tests of the cases whose Anti-HIV ELiSA tests were detected positive were sent to the Virology Laboratory of Public 
Health Institution of Turkey. Mothers whose confirmation tests and/or HIV RNA values were determined positive were included into the study. Time of HIV diagnosis of the mothers, antiretroviral treatment during pregnancy and the drugs given, delivery type, gestation week, history of early membrane rupture (EMR), labor period, and intravenous zidovudine administration during delivery were recorded. The sex of the baby, antiretroviral prophylaxis and duration and HIV viral load during delivery were examined. Presence of neural tube defect had been evaluated by ultrasonography prenatally or antenatally.

Data analyses were performed on SPSS 24.0 (IBM Corporation, Armonk, NY, USA). Continuous data were expressed as mean \pm standard deviation for normal distributions and as median (minimum-maximum) for conditions that did not fit normal distribution. For categorical data, number ( $n$ ) and percentages (\%) were used.

\section{Limitations of the Study}

Limitations of our study are as follows: its retrospective nature, small number of patients, HIV viral load could not be evaluated in all babies born from a HIV positive mother, and pregnant women received different treatment during their pregnancies or were left untreated.

\section{Results}

It was determined that a total of 15 deliveries took place from 13 HIV positive women during the course of ten years in our hospital. Mean age of the pregnant women was $27 \pm 7.5$ years. HIV diagnosis was made before pregnancy in 2 (13.3\%), during pregnancy in 7 (46.7\%) and during delivery in 6 (40\%) cases. Four (57\%) of the cases were diagnosed during pregnancy. It was seen that 2 (15.4\%) of the pregnant women diagnosed during delivery had negative Anti-HIV values in the second trimester. Eleven (84.6\%) pregnant women who did not have any Anti-HIV result were tested prior to the time of diagnosis. Antiretroviral treatment was used in 8 pregnancies $(57.1 \%)$, and 11 pregnant women $(73.3 \%)$ received intravenous zidovudine prophylaxis during delivery. Pregnant women who were administered with intrapartum zidovudine prophylaxis had $C / S$, and zidovudine prophylaxis was given through i.v infusion at a loading dosage of $2 \mathrm{mg} / \mathrm{kg}$ during delivery and at a $1 \mathrm{mg} / \mathrm{kg} / \mathrm{h}$ dosage until the umbilical cord was clamped. Two pregnant women (13.3\%) were determined to have given birth through normal spontaneous vaginal route (NSVG). While history of EMR was detected in three (20\%) pregnancies, the longest labor period was determined as 16 hours (Table 1). EMR duration was 12 hours in 2 out of 3 pregnant women and 6 hours in the other.

Table 1. Clinical and laboratory characteristics of the mothers infected with HIV

\begin{tabular}{|c|c|}
\hline & n (\%) \\
\hline $\begin{array}{l}\text { Age of pregnancy (year) } \\
\begin{array}{l}20-35 \\
>35\end{array}\end{array}$ & $\begin{array}{c}12(80) \\
3(20)\end{array}$ \\
\hline $\begin{array}{l}\text { Time of HIV diagnosis } \\
\text { Before pregnancy } \\
\text { During pregnancy } \\
\text { During delivery }\end{array}$ & $\begin{array}{c}2(13.3) \\
7(46.7) \\
6(40)\end{array}$ \\
\hline $\begin{array}{l}\text { Early membrane rupture } \\
\text { Yes } \\
\text { No }\end{array}$ & $\begin{array}{c}3(20) \\
12(80)\end{array}$ \\
\hline $\begin{array}{l}\text { Intrapartum prophylaxis } \\
\text { None } \\
\text { Intravenous zidovudine }\end{array}$ & $\begin{array}{c}4(26.7) \\
11(73.3)\end{array}$ \\
\hline $\begin{array}{l}\text { HIV-1 RNA at the period closest to delivery } \\
\quad<1000 \text { copies } / \mathrm{mL} \\
\quad \geq 1000 \text { copies } / \mathrm{mL}\end{array}$ & $\begin{array}{l}6(75) \\
2(25)\end{array}$ \\
\hline $\begin{array}{l}\text { CD4 lymphocyte count at the period closest to delivery } \\
\quad<500 \mathrm{cell} / \mathrm{mm}^{3} \\
\quad \geq 500 \mathrm{cell} / \mathrm{mm}^{3}\end{array}$ & $\begin{array}{l}4(50) \\
4(50)\end{array}$ \\
\hline
\end{tabular}


Table 2. Clinical and laboratory characteristics of the babies in contact with HIV

\begin{tabular}{|c|c|}
\hline & n (\%) \\
\hline $\begin{array}{l}\text { Sex } \\
\text { Female } \\
\text { Male }\end{array}$ & $\begin{array}{l}6(40) \\
9(60)\end{array}$ \\
\hline $\begin{array}{l}\text { Gestational age } \\
\text { Preterm (<37 weeks) } \\
\text { Term ( } \geq 37 \text { weeks })\end{array}$ & $\begin{array}{c}2(13.3) \\
13(86.7)\end{array}$ \\
\hline $\begin{array}{l}\text { ARV prophylaxis } \\
\text { Yes } \\
\text { No }\end{array}$ & $\begin{array}{c}13(86.6) \\
2(13.4)\end{array}$ \\
\hline $\begin{array}{l}\text { ARV prophylaxis starting time } \\
\quad<6 \mathrm{~h} \\
\quad \geq 6 \mathrm{~h}\end{array}$ & $\begin{array}{l}7(53.9) \\
6(46.1)\end{array}$ \\
\hline $\begin{array}{l}\text { HIV recent status } \\
\text { Infected } \\
\text { Not infected } \\
\text { Unknown }\end{array}$ & $\begin{array}{c}1(6.7) \\
10(66.7) \\
4(26.6)\end{array}$ \\
\hline ARV: Antiretroviral. & \\
\hline
\end{tabular}

Nine $(60 \%)$ of the babies born from HIV infected mothers were males and $6(\% 40)$ were females. Two (13.3\%) babies were born prematurely. Median birth gestation week of the babies was 38 weeks and 2 days (min: 34 weeks 4/7 days, max: 40 weeks). Thirteen babies (86.6\%) received antiretroviral prophylaxis (Table 2). Prophylaxis started in the first 6 hours of $53.9 \%$ of the babies receiving antiretroviral prophylaxis.

Mother of one of the babies born with normal spontaneous vaginal route had received diagnosis during delivery, and EMR ongoing for 12 hours had been detected during presentation to hospital but could not be administered with intranatal zidovudine treatment since delivery occurred shortly after presentation. Postnatally, the baby was started on zidovudine prophylaxis, and prophylaxis was terminated during follow up upon determining that HUV viral load was still negative after 8-week prophylaxis, and the other baby was taken by the mother without permission. Therefore, viral load could not be tested in the babies of the mothers who delivered with normal spontaneous vaginal route.

One of the three patients with early membrane rupture delivered with normal spontaneous vaginal route. HIV viral load was confirmed negative in two of the babies whose mothers had EMR. The other pregnant woman was a foreign national, diagnosed during delivery, had a C-section but HIV load could not be tested for the baby postnatally.

When evaluated for labor durations, two pregnant women had a 12-hour long labor and one had a 16-hour long labor. HIV viral load was negative in the babies of three patients with prolonged labor.

Out of the 11 babies (73.3\%) who were tested for HIV viral load, all but one had negative viral load. While first HIV RNA le- vels of the babies with negative HIV viral load were tested within 72 hours postpartum in 7 (63.6\%) of the babies, the viral load was tested on postpartum day 9 in $2(18.1 \%)$ and when the baby was 3-month-old in $1(0.9 \%)$. The case with a positive HIV viral load (300.000 copies $/ \mathrm{mL}$ ) on postnatal day 2 was born with a C-section in the $38^{\text {th }}$ gestation week, and while the mother's Anti-HIV was found negative in the $6^{\text {th }}$ month, it was found positive during delivery. While the mother received intravenous zidovudine prophylaxis during delivery, the baby was started on a triple (zidovudine, lamivudine, nevirapine) antiretroviral prophylaxis. During follow-up, the patient whose viral load decreased under prophylaxis was accepted as pediatric HIV and was followed with triple treatment according to guideline recommendations (8) in the first month.

\section{Discussion}

Perinatal transmission of HIV from the mother to the baby can be reduced by taking precautions prenatally, intranatally and postnatally. While vertical HIV infection transmission is $12-40 \%$ in mothers who has never received treatment, it is possible to lower this rate below $1 \%$ if necessary precautions are taken (9-11). There are international and national monitoring and treatment programs. Strategies to stop HIV epidemic in 2030 have been set up by the United Nations HIV/AIDS (UNAIDS) program (12). An HIV/AIDS control program covering the years 2019-2024 is available from the General Directorate of Public Health, Ministry of Health, Turkey to fight with HIV/ AIDS (13). One of the most important steps of this program is the continuity of surveillance studies. Considering the literature from our country, there are no other studies on perinatal HIV except for the studies and case reports by Sütçü M. et al. and İnkaya A. et al. $(14,15)$. As a center for pediatric HIV, we wished to publish our data of 10 years and emphasize the necessity of surveillance studies consisting multicenter pediatric HIV centers on the matter.

Today, thanks to increasing treatment options on HIV infection and prolonged survival, HIV positive women who are in their reproductive age show an increasing wish to have babies $(5,15)$. In a systemic review on pregnancy wishes and related factors of HIV positive women, pregnancy wish has been detected as $23 \%-58 \%$ in high income societies, whereas, in low-income societies, the rate been diagnosed before pregnancy in our study were diagnosed during their first pregnancy and had their second children form their planned second pregnancies.

In our study, HIV diagnosis was made in $6(40 \%)$ of the pregnant women during delivery. Four (66.6\%) of these pregnant women were not followed regularly for their pregnancies. One of the two pregnant women diagnosed during delivery was followed regularly. Anti-HIV test of the regularly followed pregnant woman was negative in the sixth month of her pregnancy, but her Anti-HIV test done prior to delivery 
was positive and confirmed as positive. HIV viral load of the pregnant woman detected at birth was 20.000 .000 copies/ $\mathrm{ml}$, she had a C-section, did not have a history of EMR, and received intrapartum zidovudine treatment. Since it is known that combination treatment is effective in preventing intrapartum HIV infection in babies with HIV positive mothers who did not receive antiretroviral treatment during pregnancy $(17,18)$, the baby was started on triple antiretroviral prophylaxis. Triple prophylaxis was continued in the baby whose HIV RNA was 300.000 copies/ml postnatally. The case whose control HIV viral load was detected positive is still followed by our clinic with the diagnosis of pediatric HIV. It was seen in our study that the rate of pregnant women diagnosed at delivery was $40 \%$, and the rate of those who could not receive antiretroviral treatment during their pregnancies was $46.7 \%$. In the literature, this rate has been reported as $23.2 \%$ in the study by Indarti J. et al. conducted in Endonesia, one of the countries where HIV is endemic (18). Our rates were found rather high when compared to the study by Sütçü M. et al. in our country. We believe that this situation is caused by the high rate of pregnant women who were not regularly followed (57.1\%).

Decreasing the number of pregnant women who are diagnosed during delivery and therefore go into labor with high HIV viral load for not having received antiretroviral treatment during the early phase of pregnancy is vital in the prevention of perinatal HIV transmission (19). Center for Disease Control and Prevention (CDC) and the American Obstetrics and Gynecology (ACOG) recommend HIV scanning in the early phase of pregnancy and to be repeated in the last trimester if the woman is in the risky group $(20,21)$. We are of the opinion that ensuring that HIV serology is tested at the beginning of the first and last trimester by all centers following pregnancies and using rapid diagnostic tests for unfollowed pregnant women who arrive with being in labor will significantly decrease HIV transmission from the mother to the baby (22). Despite detecting Anti-HIV negative in the second trimester of the mother of our case diagnosed with pediatric HIV, confirming a positive result prior to delivery underlines the importance of repeating Anti-HIV test in high-risk pregnant women.

History of EMR was present in three pregnant women in our study. One of these pregnant women was diagnosed with HIV at the $36^{\text {th }}$ gestation week, developed 12-hour long EMR four days after diagnosis and premature delivery occurred with emergency C-section. The desired viral suppression could not be achieved since there was a short period of time between diagnosis and delivery, and the pregnant woman went into delivery with a high viral load (726.000 copies $/ \mathrm{mL}$ ). Another pregnant woman with a 12-hour long EMR was diagnosed during delivery, presented to the hospital with being in labor and gave birth through normal spontaneous vaginal route. Both babies were started on antiretroviral prophylaxis within the first 2 hours postnatally, and HIV RNA of the babies tested at birth and follow-up was found negative. A 3-hour EMR history was present in the last pregnant woman with $E M R$, she was diagnosed during delivery, and an emergency C-section had to be performed. The woman left the hospital without permission after delivery, and HIV RNA could not be tested for the baby. In a meta-analysis investigating the effect of EMR presence and duration on HIV transmission from mother to the baby, it has been reported that there is a $2 \%$ hourly increase in the rate of HIV transmission with EMR duration in women who do not receive antiretroviral treatment during pregnancy or in those who just receive oral zidovudine.(23) In our study, vertical transmission of HIV in $2(66.6 \%)$ of the pregnant women with EMR did not occur; however, since we are unaware of the other baby's HIV status, a comment could not be made in relation to EMR duration and HIV.

When evaluated in terms of delivery type, $2(13.3 \%, 2 / 15)$ of the 13 HIV positive pregnant women who gave birth in our hospital delivered their babies through normal spontaneous vaginal route. Both of these patients were diagnosed during delivery. Postnatally, HIV RNA was detected negative in one baby, but since the pregnant woman left the hospital after delivery, HIV RNA could not be tested in her baby. Therefore, we do not know the rate of HIV in women giving birth with normal spontaneous vaginal route. C/S rate was $86 \%$ in our study and was found high when compared to literature data $(24,25)$. Eight $(61.5 \%)$ of the mothers of 13 babies (86.7\%) born with $\mathrm{C} / \mathrm{S}$ had received antiretroviral treatment during their pregnancies, postnatal HIV RNA was tested in $10(76.9 \%)$ and HIV RNA was tested positive in 1 baby (10\%). It is known that planned C-section delivery reduces the vertical transmission of HIV at a rate of $50 \%$ compared to the normal spontaneous vaginal route in pregnant women who have not received antiretroviral treatment during pregnancy $(26,27)$. There are studies reporting that normal spontaneous vaginal route does not constitute an increase in the risk of HIV transmission as regards planned $\mathrm{C}$-section in pregnant women who have received effective antiretrovirals during their pregnancy and ensured viral suppression $(28,29)$. Moreover, in the Cochrane evaluation of six studies carried out on women with HIV in the literature, it has been concluded that emergency C-section, planned $\mathrm{C}$-section and normal delivery are related to high, moderate and low risk for postnatal morbidity, respectively (30). Therefore, ACOG does not routinely recommend planned C-section performed to only prevent perinatal HIV transmission when considering the low perinatal transmission rate in this group where women have received antiretroviral treatment during pregnancy and have HIV RNA below 1.000 copies/mL (31). Again, in this group, it has been reported that EMR duration is not associated with the increase in perinatal transmission risk and that it does not sthe necessity of absolute C-section to prevent HIV transmission (31). 
In the babies of HIV infected mothers giving birth in our hospital, the rate of being infected with HIV was $9 \%(1 / 11)$. Again, in two studies conducted in our country, HIV transmission rate from mother to baby has been found at varying rates of $6.2 \%$ and $8.3 \%(14,15)$. In surveillance studies conducted in high income countries like the UK and Spain, transmission rates have gradually decreased and fell to the level of $0.4 \%(11,32)$. However, this rate is $9 \%$ in countries with limited sources and particularly HIV endemic countries of Eastern and Southern Africa (33). According to June 2019 data of the Ministry of Health of Turkey, the rate in our country is $0.8 \%$ (3). Compared to this rate, that the rate in our hospital was detected quite high could be due to the fact that the number of pregnant women unfollowed was high and there were 4 babies whose HIV statuses were unknown. In a research conducted by UNAIDS in 2013, HIV test which is routine in pregnancy is not performed in $54 \%$ of pregnant woman in low- and moderate-income countries (34). We are of the opinion that perinatal HIV transmission will be significantly reduced in our country with at least two Anti-HIV tests performed during pregnancy, early detection of cases, antiretroviral treatment given to HIV positive mother during pregnancy, going into labor with low or negative viral load, and starting antiretroviral prophylaxis in the early period.

Ethics Committe Approval: The approval for this study was obtained from Tepecik Training and Research Hospital Non-invasive Clinical Research Ethical Committee (Decision no: 2019/15-9 Date: 24.10.2019).

Informed Consent: Patient consent was obtained.

Peer-review: Externally peer-reviewed.

Author Contributions: Consept- IU, AS, EKÖ; Design- IU, EKÖ; Supervision- DYÇ, HGP, SA; Resource- IU, AS, EKÖ; Data Collection and/or Processing- IU, AS, NY; Analysis and/or Interpretation- AS, EKÖ, MYÖ; Literature Search- IU, AS, EKÖ; Writing- AS, EKÖ; Critical Review- DYÇ, MYÖ, SA, HGP, NY.

Conflict of Interest: Authors declared no conflict of interest.

Financial Disclosure: The authors declared that this study has received no financial support.

\section{References}

1. Centers for Disease Control (CDC). Unexplained immunodeficiency and opportunistic infections in infants-New York, New Jersey, California. MMWR Morb Mortal Wkly Rep 1982;31(49):665-7. [CrossRef]

2. UNAIDS. Global HIV \& AIDS statistics - 2019 fact sheet | UNAIDS. Available from: https://www.unaids.org/en/resources/fact-sheet. Accessed date: March 7, 2020. [CrossRef]

3. T.C. Sağlık Bakanlığı. HIV-AIDS istatistik. Available from: https://hsgm. saglik.gov.tr/tr/bulasici-hastaliklar/hiv-aids/hiv-aids-liste/hıv-aidsistatislik.html. Accessed date: March 7, 2020. [CrossRef]

4. World Health Organization (WHO). HIV/AIDS. Available from: https:// www.who.int/news-room/fact-sheets/detail/hiv-aids. Accessed date: March 7, 2020. [CrossRef]
5. Kang JS, Lee SH, Lee S, Lee JE, Lee SO, Kim SC, et al. Changing trends in pregnancy and childbirth among women living with human immunodeficiency virus at a tertiary hospital in Korea: A 28-year experience. Infect Chemother 2019;51(1):28-34. [CrossRef]

6. Raffe S, Curtis H, Tookey P, Peters H, Freedman A, Gilleece Y, et al. UK national clinical audit: Management of pregnancies in women with HIV. BMC Infect Dis 2017;17(1):1-6. [CrossRef]

7. Long S, Pickering LK. Epidemiology and prevention of HIV infection in children and adolescents. In: Long S, Prober C, Fischer M (eds). Principles and Practice of Pediatric Infectious Diseases. $5^{\text {th }}$ ed. Philadelphia, PA: Elsevier, 2017. [CrossRef]

8. Clinical Info HIV.gov. Transmission and Mode of Delivery Intrapartum Care Perinatal AIDSinfo. Available from: https://aidsinfo.nih.gov/ guidelines/html/3/perinatal/182/transmission-and-mode-of-delivery. Accessed date: March 8, 2020. [CrossRef]

9. Connor EM, Sperling RS, Gelber R, Kiselev P, Scott G, O'Sullivan MJ, et al. Reduction of maternal-infant transmission of human immunodeficiency virus type 1 with zidovudine treatment. N Engl J Med 1994;331:1173-80. [CrossRef]

10. Townsend CL, Cortina-Borja M, Peckham CS, De Ruiter A, Lyall H, Tookey $P A$. Low rates of mother-to-child transmission of HIV following effective pregnancy interventions in the United Kingdom and Ireland, 20002006. AIDS 2008;22(8):973-81. [CrossRef]

11. Peters H, Francis K, Sconza R, Horn A, Peckham CS, Tookey PA, et al. UK mother-to-child HIV transmission rates continue to decline: 2012-2014. Clin Infect Dis 2017;64(4):527-8. [CrossRef]

12. UNAIDS. 2025 AIDS Targets: 2025 Target setting and 2020-2030 resource needs and impact estimation. Available from: https://www. unaids.org/en/topics/2025_target_setting. Accessed date: March 10, 2020. [CrossRef]

13. T.C. Sağlık Bakanlı̆̆ı. Türkiye HIV/AIDS Kontrol Programı. Available from: https://hsgm.saglik.gov.tr/depo/birimler/Bulasici-hastaliklar-db/ hastaliklar/HIV-ADS/Tani-Tedavi_Rehberi/HIV_AIDS_Kontrol_Programi.pdf Published 2019. Accessed date: March 7, 2020. [CrossRef]

14. Sütçü $M$, Aktürk $H$, Somer A, Hançerli Törün S, Ince $Z$, Çoban A, et al. Anneden bebeğe HIV geçişi: sekiz yıllık deneyim. Mikrobiyol Bul 2015;49(4):542-53. [CrossRef]

15. Inkaya AÇ, Örgül G, Halis N, Alp Ş, Kara A, Özyüncü Ö, et al. Perinatal outcomes of 25 hiv-infected pregnant women: Hacettepe University experience. J Turk Ger Gynecol Assoc 2020;21(3):180-6. [CrossRef]

16. Martins A, Alves S, Chaves C, Canavarro MC, Pereira M. Prevalence and factors associated with fertility desires/intentions among individuals in HIV-serodiscordant relationships: a systematic review of empirical studies. J Int AIDS Soc 2019;22(5):e25241. [CrossRef]

17. Kara A, Bayram N, Devrim I. Intrapartum HIV enfeksiyonunda zidovudin, lamivudin ve nevirapinden oluşan postpartum antiretroviral profilaksisi. J Pediatr Infect 2015;9(4):178-80. [CrossRef]

18. Indarti J, Yunihastuti E, Kurniati N, Aprilia B, Pamungkas DT, Chiprion $A T$, et al. Pregnancy Profile and Infant Outcomes Among HIV Infected Women Who Delivered in Cipto Mangunkusumo Hospital. Acta Med Indones 2020;52(1):55-62. [CrossRef]

19. Abebe ZZ, Mengistu MY, Gete YK, Worku AG. Mother-to-Child HIV Transmission among Infants Born to HIV-Positive Women in Amhara National Regional State, Ethiopia. Recent Adv Biol Med 2020;1:1-7. [CrossRef]

20. Centers for Diseases and Prevention (CDC). Screening Recommendations: Clinician Timeline for Screening Syphilis, HIV, HBV, HCV, Chlamydia, and Gonorrhea. Available from: https://www.cdc.gov/nchhstp/ preventionthroughhealthcare/preventiveservices/index.htm. Accessed date: March 12, 2020. [CrossRef]

21. American College of Obstetrics and Gynecology Committee on Obstetric Practice. ACOG committee opinion No. 418: Prenatal and perinatal human immunodeficiency virus testing: Expanded recommendations. Obstet Gynecol 2008;112(3):739-42. [CrossRef] 
22. Bulterys M, Jamieson DJ, O'Sullivan MJ, Cohen MH, Maupin R, Nesheim $S$, et al. Rapid HIV-1 testing during labor: A multicenter study. J Am Med Assoc 2004;292(2):219-23. [CrossRef]

23. Bulterys MB, Fowler MG, Hanson IC, Lemay M, Mayaux MJ, Mofenson $L$, et al. Duration of ruptured membranes and vertical transmission of HIV-1: A meta-analysis from 15 prospective cohort studies. AIDS 2001;15(3):357-68. [CrossRef]

24. Holzmann APF, Silva CS de O, Soares JAS, Vogt SE, Alves CDR, Taminato $M$, et al. Preventing vertical HIV virus transmission: hospital care assessment. Rev Bras Enferm 2020;73(3):e20190491.[CrossRef]

25. Loh M, Thoon K, Mathur M, Kathirvel R. Management of HIV-positive pregnant women: a Singapore experience. Singapore Med J 2020;1-16. [CrossRef]

26. International Perinatal HIV Group. The mode of delivery and the risk of vertical transmission of human immunodeficiency virus type 1: A meta-analysis of 15 prospective cohort studies. N Engl J Med 1999;340(13):977-87. [CrossRef]

27. Parazzini F, Ricci E, Di Cintio E, Chiaffarino F, Chatenoud L, Pardi G. Elective caesarean-section versus vaginal delivery in prevention of vertical HIV-1 transmission: A randomised clinical trial. Lancet 1999;353(9158):1035-9. [CrossRef]

28. Aho I, Kaijomaa M, Kivelä P, Surcel HM, Sutinen J, Heikinheimo O. Most women living with HIV can deliver vaginally-National data from Finland 1993-2013. PLoS One 2018;13(3):e0194370. [CrossRef]
29. Briand N, Jasseron C, Sibiude J, Azria E, Pollet J, Hammou Y, et al. Cesarean section for HIV-infected women in the combination antiretroviral therapies era, 2000-2010. Am J Obstet Gynecol 2013;209:335.e1-335. e12. [CrossRef]

30. Read JS, Newell MK. Efficacy and safety of cesarean delivery for prevention of mother-to-child transmission of HIV-1. Cochrane Database Syst Rev 2005;1(4):CD005479. [CrossRef]

31. ACOG Committee Opinion No. 751: Labor and delivery management of women with human immunodeficiency virus infection. Obstet Gynecol 2018;132:131-7. [CrossRef]

32. Jiménez De Ory S, Ramos JT, Fortuny C, Gonzalez-Tome MI, Mellado MJ, Moreno $D$, et al. Sociodemographic changes and trends in the rates of new perinatal HIV diagnoses and transmission in Spain from 1997 to 2015. PLoS One 2019;14(10):e0223536. [CrossRef]

33. UNAIDS. United Nations Joint Programme on HIV/AIDS. UNAIDS Data 2020. Available from: https://www.unaids.org/en/topic/data. Accessed date: March 7, 2020. [CrossRef]

34. UNAIDS. The Gap Report. Available from: https://www.unaids.org/en/ resources/documents/2014/20140716_UNAIDS_gap_report. Accessed date: July 13, 2020. [CrossRef] 